\title{
INTERNATIONAL TOURISM AND HOSPITALITY ACADEMY AT SEA: PROGRAM ISKUSTVENOG UČENJA NA RNOV SHABAB OMAN II
}

\section{INTERNATIONAL TOURISM AND HOSPITALITY ACADEMY AT SEA: EXPERIENTIAL LEARNING PROGRAM ON RNOV SHABAB OMAN II}

SAŽETAK: Godine 2021. dvadeset i sedam studenata s raznih sveučilišta imalo je priliku sudjelovati u programu iskustvenog učenja u području turizma, održivosti i kulture koji se 28 dana odvijao na brodu Kraljevske mornarice Omana. Metoda doživljajnog učenja sve je popularnija obrazovna filozofija u području turizma i ugostiteljstva. U ovome se članku opisuje to iskustvo te se daju primjeri kad se učenje događalo kao i što su studenti time dobili. Također se daju rezime puta, zatim kulturni i praktični doživljaji te diskusije o turizmu i održivosti. Konačno se preporuča dalje održavanje ovakvih obrazovnih plovidbi s obzirom na mnoge mogućnosti za učenje u jedinstvenim okruženjima.

KLJUČNE RIJEČI: iskustveno učenje, obrazovanje u turizmu, ITHAS

ABSTRACT: In 2021, a 28-day experiential learning program offered 27 university students an opportunity to sail on a Navy ship and learn about tourism, sustainability, and culture. Experiential education is an educational philosophy that is increasingly popular in the tourism and hospitality sector. This paper overviews the experience, with examples of times when learning took place as well as what students took out of the trip. The overall trip is summarized, and then cultural and practical experience, tourism, and sustainability are discussed. As this educational voyage presented the students with many opportunities for learning in unique environments future programs like this are recommended.

KEY WORDS: experiential learning, tourism education, ITHAS

Joshua Kattsir, undergraduate student at Brock University, Applied Health Sciences Department, Canada, e-mail: joshkattsir@gmail.com 


\section{UVOD}

International Tourism and Hospitality Academy at Sea (ITHAS) program je iskustvenog učenja, pilot projekt prof. dr. sc. Nevenke Čavlek s Ekonomskog fakulteta Sveučilišta u Zagrebu. Projekt je razvijen kao program intenzivnog učenja tijekom kojega studenti iz cijeloga svijeta plove na brodu oko osam dana i proučavaju turizam i ugostiteljstvo. Kroz partnerstva sa sveučilištima iz mnogih zemalja Čavlek i Sveučilište u Zagrebu omogućili su mnogim studentima da istovremeno budu u trostrukoj ulozi: studenta, turista i budućih stručnjaka (Čavlek, 2015:102). Na putovanjima ITHAS-a, studenti se hvataju u koštac sa stvarnim situacijama kako bi odmah primijenili u praksi teoriju koju uče te su do sad izvještavali kako su u kratkom vremenu naučili više nego cijeli semestar na klasičnoj nastavi, ali i uz nezaboravne uspomene i prijateljstva za cijeli život. Od prvog ITHAS-a 2005. godine održano je ukupno njih četrnaest, uglavnom u Hrvatskoj i nekoliko europskih zemalja uz partnerske institucije iz raznih zemalja i kultura poput Kanade, Španjolske, Njemačke i Mađarske. Poseban ITHAS odvio se od 7. studenog do 5. prosinca 2021. godine zahvaljujući jednoj zemlji partneru - Omanu.

Dugogodišnja suradnica na ITHAS-u je prof. dr. sc. Heba Aziz iz partnerske institucije German University of Technology (GUtech) u Omanu. Godina 2020. bila je posebna iz dva razloga: (1) 50. obljetnica Nacionalnog dana Sultanata Omana te (2) obilježavanja prve Expo izložbe u arapskom svijetu. Uz velikodušno sponzorstvo Kraljevske mornarice Omana, profesorice Čavlek i Aziz podigle su ITHAS na novu razinu. Studenti su iz Omana krenuli na dvadesetosmodnevnu plovidbu na brod omanske mornarice Shabab Oman II. Posjetili su sve zemlje u sklopu GCC-a (Gulf Cooperation Countries) i usput proučavali turizam i kulturu uz poseban naglasak na održivost, a posebna točka bila je Dubai i

\section{INTRODUCTION}

The International Tourism and Hospitality Academy at Sea (ITHAS) is an experiential education program piloted by Professor Nevenka Čavlek, PhD, University of Zagreb, Faculty of Economics \& Business. It was designed as an intensive study program, in which students from around the world would learn about tourism and hospitality while living on a boat for roughly eight days. Čavlek and the University of Zagreb have partnered with many countries, and students from around the world take part as students, as tourists, and as future experts (Čavlek, 2015:102). On ITHAS trips, students get thrown into real-world situations and can thus immediately apply the theory they learn to practice, and so far, they have reported learning more in that short period than in a full semester of classes while bringing home memories and friends for life. ITHAS first ran in 2005, and there have been 14 iterations since. In the past, the program has been held mainly in Croatia and in several European countries. There are partner institutions from many different cultures, including Canada, Spain, Germany, Hungary. From November 7 to December 5, 2021, a special ITHAS took place thanks to one partner country, Oman.

One long-time ITHAS partner is Professor Heba Aziz, PhD, and the institution she works for, the German University of Technology in Oman (GUtech). The year 2020 was a special for two reasons: (1) it was the $50^{\text {th }}$ National day for the Sultanate of Oman, and (2) it was slated to be the first time Expo was hosted in the Arab world. Working with Cavlek and Aziz, the Sultanate of Oman and the Omani Royal Navy generously sponsored a fantastic version of ITHAS on a new scale. Beginning in Oman, students sailed with the Omani Navy on the Shabab Oman II ship for 28 days. They visited all Gulf Cooperating Countries (GCC), learning about tourism and culture in each with a focus on 
svjetska izložba Expo. Program je predviđao vođeni i slobodni dio kako bi studenti što bolje upoznali svaku zemlju. Tijekom plovidbe studenti su sudjelovali u intenzivnim modulima predavanja i seminarske nastave u kojoj su poticani na razmišljanje o svojim iskustvima u svakoj pojedinoj zemlji te su prolazili edukaciju jedrenja uz vodstvo časnika Kraljevske mornarice Omana. Posada broda i studenti postali su jedna velika obitelj u kojoj svi uče jedni od drugih. Jedinstvena prilika iskustvenog učenja opisana je u ovome član$\mathrm{ku}$, kao i ishodi učenja iteracije ITHAS-a 2021 s egidom "Povezujući umove, stvarajući budućnost: Uloga održivosti i turizma“.

Iskustvena pedagogija podrazumijeva učenje sudjelovanjem i praksom. Njezine metode pokazale su se učinkovitima u spajanju akademskih i praktičnih vještina koje su važne svima zaposlenima (Ruhanen, 2006). Aktivnim sudjelovanjem, iskustveno učenje znači činiti uz klasično čuti/slušati i vidjeti, što su prakse tradicionalnih učionica (Ruhanen, 2006:37). Općenito su katedre za turizam i ugostiteljstvo na zapadnim učilištima usporene te se još uvijek oslanjaju na akademsku komponentu s malo poveznica s praksom i djelatnostima na terenu (Dicen et al., 2019). S druge strane, u Jugoistočnoj Aziji (Dicen et al., 2019) postoji svijetao primjer obrazovanja u turizmu i ugostiteljstvu koji usvaja iskustveno obrazovanje. Dicen i njegovi kolege (2019) izvijestili su da sveučilišta na Tajlandu intenzivno investiraju u iskustveno učenje svojih studenata dajući prioritet doživljajnom obrazovanju putem usmjeravanja na povezivanje $\mathrm{s}$ praksom te dajući im priliku za vježbanje vodstva. Za uzvrat poslovni subjekti nude studentima trodnevne studijske boravke $\mathrm{u}$ hotelima s pet zvjezdica, na primjer (Dicen et al., 2019). Iskustveno učenje stječe sve veću popularnost u edukaciji u području turizma (Čavlek, 2015). sustainability, with the final stop being Dubai to experience and learn from Expo. Guided programming and free time to explore was arranged in each country. Between the countries, students learned from intense academic lectures and reflections on their experiences in each country, as well as sailing taught by officers of the Omani Navy. The ship's crew and the students were to become one big family, learning from one another. This was a unique experiential education opportunity, and in this paper the learning outcomes of the 2021 iteration of ITHAS entitled "Connecting Minds, Creating the Future: The Role of Sustainability and Tourism" will be explored.

Experiential education is learning through participation and practice. Experiential education approaches have shown to be effective at connecting academics to practical skills that will help in the workforce ( $\mathrm{Ru}$ hanen, 2006). By engaging actively, experiential learning includes 'doing' as well as the classic 'hearing' and 'seeing' that takes place in traditional classrooms (Ruhanen, 2006:37). Broadly speaking, Western institutions' hospitality departments have been slow-moving, still leaning on the academic component with little industry contact and practical activity (Dicen et al., 2019). Conversely, one prominent example of tourism and hospitality education transitioning towards experiential education can be seen in South East Asia (Dicen et al., 2019). Dicen and colleagues (2019) described that Thai universities have been prioritizing employability for their tourism students through investing heavily in experiential education and focusing on connections with industry, and having students practice leadership. One instance showing this connection to industry is the general manager of a five-star hotel hosting 200 students on a 3-day field experience trip at no cost to the students or university, seen as a way of giving back (Dicen et al., 2019). Experiential learning has increasingly gained popularity in tourism education (Čavlek, 2015). 


\section{ITHAS 2021: PRIKAZ ISKUSTVA}

Ovaj ITHAS uvelike je obilježen kretanjem. Profesorice Čavlek i Aziz organizirale su akademski program za studente uz pomoć svojih sveučilišta, a mornarica Omana bila je zadužena za organizaciju programa edukacije studenata u jedrenju i mornaričkim vještinama. Na kopnu je program organiziran u usputnim lukama iz zemalja GCC-a u skladu s akademskim programom i kako bi se studentima dala i praktična motrišta. Dok su se na prošlim ITHAS-ima koristili turistički brodovi, ova verzija je prvi puta imala pristup mornaričkom jedrenjaku pa je stoga i prvi puta mogla ponuditi, uz akademsku komponentu, i program edukacije u mornaričkim vještinama. Iskustveno obrazovanje na brodu odvijalo se u četiri kategorije: jedrenje/plovidba, kultura, turizam i održivost. Turizam i održivost uključeni su u proučavanja šest zemalja s menadžerske točke gledišta kao i iz perspektive turista koji posjećuju znamenitosti uz vodiče ili provodeći slobodno vrijeme u destinacijama. Ishodišta učenja u modulu jedrenja uključili su vodstvo, timski rad i disciplinu. Kulturalni aspekti obuhvaćali su doživljaje studenata iz cijeloga svijeta u međusobnom kontaktu i kontaktu s različitim običajima posjećenih destinacija. Svi obrazovni aspekti ITHAS-a 2021 zajedno su kulminirali intenzivnim i informativnim obrazovnim iskustvom.

\subsection{Kulturno i praktično iskustvo}

Putovanje je počelo susretom svih studenata u hotelu u Muscatu. U Omanu su posjetili GUtech i grad Muscat. Zatim su studenti iz Omana povezli inozemne kolege u svojim automobilima u obilazak lokalnih znamenitosti. Turisti obično na odmoru mogu puno naučiti o lokalnoj kulturi, ali ništa se ne može usporediti s iskustvom kada vas vode i razgovaraju s vama ljudi koji tamo i žive. Upravo je tada počeo intenzivan program

\section{ITHAS 2021: THE EXPERIENCE IN REVIEW}

There were many moving parts on this iteration of ITHAS. Čavlek and Aziz organized an academic program for the students, with support from their universities. The Omani Navy organized a sailing and navy program, referring to students as trainees. A shore programme organised at the different ports of call that included all GCC countries to complement the academic programme and allow the students practical perspectives. Past ITHAS programs have used boats as vessels; as the first iteration with access to a navy sailing ship, this is the first in which the tourism-focused academic component has been balanced with the sailing-focused training programme. The experiential education on this trip can be discussed in four categories: sailing, culture, tourism, and sustainability. The tourism and sustainability aspects come from exploring six countries, seeing them from the management side as well as from the perspective of tourists, seeing highlights through guided tours as well as having free time to roam. The sailing aspects of the learning outcomes of the trip include leadership, teamwork, and discipline components. The cultural aspect looks at students from around the world coming to a new area with different customs. Together, the educational aspects of ITHAS 2021 culminate to create an intense and informative educational experience.

\subsection{Cultural and practical experience}

The trip began with all of the students meeting in a hotel in Muscat. The Oman itinerary consisted of a tour of GUtech, followed by a city tour of Muscat. Afterwards, the Omani students picked up the rest of the students in their cars and showed them the local spots. On typical vacations, travelers may learn about local culture, but nothing can replicate being shown around by (and interacting with) people actually from there. 
učenja kulture - već su prvoga dana razlike bile izrazite.

Mnogo toga se ispreplelo kako bi učinilo ovaj ITHAS prilikom za jedinstveno i snažno iskustveno učenje, a možda je najvažniji čimbenik bila mornarička struktura i disciplina. Shabab Oman II je jedrenjak dužine 85,8 metara koji poslužuje 10 časnika i 44 ostalih članova posade. Iako se na brodu školuju kadrovi Kraljevske mornarice Sultanata Omana, glavna mu je funkcija privlačenje turista. Kad je kapetan pristao ugostiti ITHAS, $\mathrm{s}$ časnicima je osmislio prilagođeni program kako bi studenti mogli, uz vježbanje mornaričkih vještina, imati i vremena za akademski program te energije za istraživanje zemalja. Tako je ITHAS 2021 dobio posebno osmišljenu školu jedrenja.

U školi jedrenja studenti su dobili posebna znanja kao i važne meke vještine (npr. vodstvo, timski rad, disciplina). Od prvoga dana studenti su bili podijeljeni u timove u kojima su ostali cijelo vrijeme putovanja. Ti su timovi zajedno svaki dan dežurali na moru, učili i vježbali mornarske tehnike, kao npr. kormilarenje, motrenje horizonta, itd. Časnici su studente podučavali osnovama navigacije i kartografiji, tj. čitanju pomorskih karata, a to se praktično primjenjivalo tako da su studenti svakih 15 minuta u svojim dežurstvima imali zadatak odrediti lokaciju broda na karti koristeći koordinate geografske dužine i širine te ispraviti kurs broda. Rad s konopima također je bio jako važan; učilo se potezanje konopa za namještanje jedara, prepoznavanje desetaka raznih konopa na brodu kao i vezanje čvorova kao npr. pašnjak.

Možda i važnije od specifičnih znanja, škola jedrenja studentima je dala prilike za vježbanje svevažnih mekih vještina, jer su časnici inzistirali na aspektima timskog rada i vodstva. Jedan je student odabran za voditelja cijele grupe, a svaki od četiri tima imao je i svog vođu. To se mijenjalo svakih nekoliko dana. Ovime su studenti bili primorani preuzeti odgovornosti i izaći iz svojih zona ugode
This trip with the Omanis was when the intense cultural learning began, and even from the first day the differences were stark.

Many things meshed together to make this ITHAS a unique and powerful experiential education opportunity, and perhaps the most prominent factor that set it apart was the sailing and general navy aspect of structure and discipline. Shabab Oman II is an 85.8-metre sailing ship that is operated by a complement of 10 officers and 44 crew. The ship trains Omani Navy personnel, but it is used to draw tourists to Oman, not as a navy vessel. When the captain agreed to this ITHAS program, he and the officers designed a toned-down program to enable the students to learn many of the skills like trainees, but with time for academic programming and energy to explore countries. The sailing course was thus designed especially for ITHAS 2021.

The sailing course taught students specific knowledge as well as practice important soft skills (e.g., leadership, teamwork, discipline). From the first day, students were divided into groups that were to be their team of trainees for the duration of the trip. These teams did shifts together every day at sea, learning and practicing sailing techniques, such as steering the ship and looking out for objects on the horizon. Officers taught students basic navigation and cartography, including how to read naval maps, and this was put into practice by students having to 'fix' the ship's location-identify where it is on the map using longitude and latitude coordinates-every 15 minutes on their shifts. Ropework was also a big focus; trainees were taught to pull ropes to tighten and adjust the sails, to identify dozens of ropes on the ship, and to tie relevant sailing knots such as the bowline.

Perhaps even more important than the specific knowledge, the sailing course allowed students to practice important soft skills. The ship's officers stressed the teamwork and leadership aspects. One trainee was selected as the overall leader, and each of the four teams had an additional student leader. 
kao i naučiti slušati i vjerovati jedni drugima. Ovi učinci umnogostručili su se pod utjecajem mornaričke discipline koja je uključivala dnevne zadatke poput čišćenja, okupljanje na zbornom mjestu ranom zorom te pomaganje mornarima u postavljanju jedara.

\subsection{Iskustvo turističkog obrazovanja}

Program ITHAS-a prvenstveno je usmjeren na obrazovanje za turizam. ITHAS 2021 poveo je studente u šest zemalja-Oman, Kuvajt, Saudijsku Arabiju, Bahrein, Katar i Ujedinjene Arapske Emirate (UAE) - te im pokazao kako žive turisti i menadžeri u turizmu. U svakoj zemlji studenti su išli u razgled važnih lokaliteta i atrakcija (npr. sveučilišta, muzeja, mjesta svjetske baštine). $\mathrm{Na}$ svim su mjestima lokalni vodiči objašnjavali značaj lokaliteta, njegovu povijest i učinak na stanovništvo te utjecaj na gospodarstvo i kulturno značenje. Umjesto čitanja studija slučaja u akademskom okruženju, ovaj je način studentima približio perspektivu menadžmenta u turizmu na primjerima iz stvarnog svijeta.

Dvadeset i sedam studenata ITHAS-a 2021 došlo je iz 11 različitih zemalja s 9 sveučilišta. Ta raznolika porijekla dala su različite perspektive, kako u akademskom segmentu tako i u pogledu individualne interakcije. Tako su se Kanađani, Hrvati i Omanci, koji žive vrlo različite živote tisućama kilometara udaljeni na brodu Shabab Oman II, integrirali u jedan tim. Akademska komponenta programa uključivala je mnoge rasprave u kojima su se mogle razmjenjivati brojne nove ideje koje su proizlazile iz raznovrsnosti samih studenata. Svaka zemlja suočava se s izazovima; tako su, na primjer, Saudijci napomenuli da njihova vlada svake godine sruši i nanovo izgradi cijeli grad, a Mađari su naveli da samo $10 \%$ njihove energije dolazi iz obnovljivih izvora. Čak i u nekim zemljama poput Njemačke, koja je daleko uznapredovala u održivom razvoju, još uvijek ima mnogo prostora za napredak pa su
This was rotated every few days. This forced students to take responsibility and step outside of their comfort zones, as well as listen and trust to each other. The navy discipline aspect amplified these effects, with students having daily cleaning tasks, mustering early most mornings, and assisting the crew like with setting the sails.

\subsection{Tourism education experience}

Tourism education is the primary focus of the ITHAS program. ITHAS 2021 brought students to six countries-Oman, Kuwait, Saudi Arabia, Bahrein, Qatar, and United Arab Emirates (UAE) - and showed them life as tourists as well as life as tourism managers. In each country, the students were given tours of important locations and landmarks (e.g., universities, museums, world heritage sites) with relevance to tourism and/ or local culture. At all sites, local guides explained one or more of the following to students: what is the site, what is the history, how it affects locals, how it affects the economy, and what is the cultural significance. Rather than having to read case studies in a classroom, this allowed the students to see the management perspective of tourism put into practice with real-world examples.

The 27 students of ITHAS 2021 were from a diverse background - 9 Universities and 11 nationalities. Having people from this many backgrounds offered many different perspectives, both for academic segments as well as individual interaction. For example, Canadians, Croatians, and Omanis live thousands of kilometres apart with many differences in their day-to-day lives, yet on Shabab Oman II they merged into a team. The academic components of the program were all designed to hold lots of discussion, and many fresh ideas were able to be shared as a result of having such a diverse pool of students. Each country faces challenges; for example, the Saudi Arabians talked about their government building up and tearing down 
tako njihovi studenti kritizirali činjenicu da mnoge kompanije daju svojim zaposlenicima skupe automobile na upotrebu.

Kulturni šok bio je možda još bitniji izvan nastave. Za studente iz Omana, Katara, Bahreina, Emirata i Saudijske Arabije bio je to život na mornaričkom brodu s ljudima iz cijeloga svijeta. Taj život imao je svoju kulturu, disciplinu i općenito iskustvo zajedničkog života s posadom. Za studente iz Hrvatske, Mađarske, Njemačke i Kanade gore navedeno je bilo isto izazovno uz prilagodbu na nove običaje i ogromne razdaljine od domova. Posjeti zemljama bili su popraćeni razgledima uz stručno vođenje, ali bilo je i vremena za samostalno istraživanje i međusobnu komunikaciju sa stanovništvom pa su u kratkom vremenu saznali mnogo više o svijetu nego što su to mogli na fakultetu. Ipak, upravo su se na brodu pomicale granice zone ugode. Kultura Bliskog istoka vrlo je različita od europske ili sjeverno-američke, a $\mathrm{u}$ dijeljenom prostoru od manje od $100 \mathrm{kva}$ dratnih metara nije bilo izbora nego uklopiti se. Prilagodba novim običajima, nepoznavanje kolega, izgradnja veza tako čvrstih kao u obitelji u samo mjesec dana bilo je iskustvo koje nadmašuje sva ostala. Do kraja putovanja studenti su bili poput obitelji međusobno, s mornarima, časnicima i kapetanom. Bilo bi teško ponoviti ovo iskustvo međusobnog života i učenja.

Nakon Omana stali smo u Kuwaitu. Tamo su studenti posjetili Sveučilište u Kuvajtu, Američki kulturni centar i Tornjeve Kuvajta, a navečer je bio izbor: slobodno vrijeme ili vođena tura kroz tržnicu $\mathrm{Al} \mathrm{Mu}$ barekia. Na svim mjestima vodiči su govorili o Kuwaitu općenito kao i o specifičnostima mjesta. Najdulje smo se zadržali u Američkom kulturnom centru gdje je izložena jedna od najvećih kolekcija islamskih spomenika na svijetu. Tijekom vođenja studenti su imali priliku detaljno upoznati čuvenu trgovinu odijela gdje ih je vlasnik obukao u abaye i dishdashe za poziranje i pričao im o povijesti souqa. Također se pohvalio registar- a full city every year, and the Hungarians discussed only $10 \%$ of their energy being renewable. Even if some countries like Germany are further ahead in terms of sustainable development than others, there are still many ways to improve. Thus, the German students discussed that companies giving many expensive company cars for employees to use.

The culture shock was perhaps even more relevant outside of the classroom. For Omani, Qatari, Bahraini, Emirati, and Saudi students, they were living on a Navy ship with people from around the world and learning lots about the Gulf countries. Life on a navy ship came with its own culture, discipline, and general experience co-living with a crew. For Croatian, Hungarian, German, and Canadian students, they faced the above while also adapting to new customs a huge distance from their homes. While visiting countries, they experienced guided tours as well as some time to explore and interact with locals and in a short time learned more about the world than a classroom could emulate. On the boat, though, is where the comfort zone boundaries were really pushed. The culture in the Middle East is very different from that of Europe or North America, and in a shared space of under 100 metres there is no choice but to be immersed. Adapting to new customs, not knowing anybody, building bonds as tight as family within a month is a transcendent experience. By the end of the trip, the students were a family with each other, the crew, the officers, and the captain. It would be hard to replicate the experience of living and learning from one another.

After Oman, the first stop was Kuwait. There, the students visited the University of Kuwait, the Americani Culture Centre, and Kuwait Towers. The evening had an option of free time or a guided tour through Al Mubarekia (a souq). In these places the guides talked about Kuwait broadly as well as their specific sites. The Americani Culture Centre was the longest visit, where one of the largest collections of Islamic monuments in 
skim pločicama svojih Lamborghinija koje je imao, kao i slikama sa slavnim ljudima u svom dućanu poput Billa Gatesa. To je samo jedan primjer kulturnog iskustva ITHAS-a 2021 koje se ne može ponoviti u uvjetima fakultetske nastave. Slično se događalo i u ostalim zemljama koje smo posjetili.

\subsection{Iskustvo predavanja i vježbi o održivosti}

Iskustveno obrazovanje razlikuje se od tipičnog učenja u tome što studenti uče iz prakse na terenu, ali i na nastavi, što se onda odmah provodi u praksi. Što se tiče održivosti, nastava ne može simulirati iskustvo iz prve ruke kada je student bačen da pliva i sam osjeti kako stvari funkcioniraju. Dakako, stadion Al Janoub u Kataru jedan je od najistaknutijih primjera gdje se to pokazalo. Naime, već smo na brodu slušali mnoga predavanja o turizmu i Ciljevima održivog razvoja te o tom stadionu sagrađenom za Svjetski kup FIFA-e u studenom 2022. Na posebnoj turi samo za nas koju je vodio projektni menadžer studenti su mogli saznati sve o planiranju i izgradnji stadiona, o njegovoj održivosti i o drugim važnim karakteristikama. Osvrćući se kasnije na iskustvo viđenog i koristeći se stečenim teorijskim znanjem na predavanjima, studenti su mogli bolje analizirati razvoj stadiona za Svjetski kup u sklopu tog mega događaja. Vidjeli su održivost na djelu u sustavima za hlađenje koji recikliraju energiju, četiri vrste recikliranja, javni promet u i iz grada, krov koji zadržava hladni zrak i dugoročne planove po kojima bi se donirale tisuće stolica. Stadion Al Janoub jedan je od mnogih primjera na kojima su studenti mogli naučiti kroz praktično iskustvo.

Mega događaji zahtijevaju planiranje, izvedbu i ostavštinu. U UAE-u studenti su imali pet dana za posjet i učenje o Svjetskoj izložbi Expo 2020. Expo (također poznat i kao svjetski sajam) svjetski je događaj koji se održava svakih nekoliko godina s ciljem the world is displayed. Students who partook in the guided tour were treated to a long lesson in a famous suit shop, where the owner dressed them in abaya and dishdasha, posed them, and talked about the history of the souq. He also showed off license plates from the Lamborghinis he owned in the past and pictures with famous people like Bill Gates at his shop. This is an example of the type of culture students learned from and experienced on ITHAS 2021 that cannot be recreated in a classroom. The next countries continued in a similar fashion.

\subsection{Sustainability education and training experience}

Experiential education stands apart from typical learning in that students can both learn from practice in the field or learn from the lessons and then put it into practice immediately. When looking at sustainability, a classroom cannot simulate firsthand experience of being thrown into the field and getting to experience how things function. However, Al Janoub Stadium in Qatar is one of the most prominent ways this was demonstrated. Namely, at this point on the boat there had been many academic lectures around tourism and the Sustainable Development Goals and that it was built for the November 2022 FIFA World Cup. On the private tour the project manager explained to the students how the stadium was designed and constructed, its sustainability, and other important features. Reflecting on their own experiences later on board the ship and applying their academic lessons in the field, the students were able to analyze the development of the World Cup stadium, part of a mega event. They got to see sustainability put into effect in the forms of a cooling system which recycled energy, four types of recycling, public transit to and from the city, a roof enclosing the stadium to keep the cold air in, and legacy plans for the stadiums such as donating thousands of chairs. Al Janoub Stadium is one of many 
da sve zemlje diljem svijeta prikažu svoja postignuća. U ispitivanju prije događaja stanovnici Dubaija otkrili su da vole svoj grad i podržavaju Expo 2020 u svome gradu te su izrazili mišljenje da bi se Dubai trebao natjecati za organizaciju drugih mega događaja (Tournois, 2018). Expo 2020 ima za temu „Povezivanje umova, stvaranje budućnosti," i podteme održivost, mobilnost i prilike (Expo 2020 Dubai, n.d.). Uz slobodno vrijeme za istraživanje izložaka iz 192 zemlje, studenti su imali priliku učiti iz inicijativa koje se događaju diljem svijeta. Na primjer, u Laosu su razvili učinkovitiju tehnologiju za čišćenje milijuna neeksplodiranih bombi u toj državi kako bi oslobodili što više zemlje za poljoprivredni razvoj. Drugi primjer je belgijski plan virtualne verzije glavnog grada za nadziranje stvari poput semafora uz istodobnu mogućnost simulacije potencijalnih promjena na ekonomičniji i okolišno prilagođen način. Kako su studenti naučili, Dubai ima snažan plan za budućnost izložbe Expo 2020 prema kojemu će se iskoristiti više od $85 \%$ izgrađenog prostora (Halligan, 2021), što je održivije od mnogih prošlih mega događaja. Okoliš poput onoga na Expo-u 2020 daje stotine raznovrsnih lekcija iz kojih se može naučiti, a ova vrsta iskustvenog učenja na ITHAS-u 2021 nešto je što se ne može simulirati u učionici.

\section{ZAKLJUČAK}

Na ovome putovanju studenti su učili o kulturi, turizmu, održivosti, jedernju i mogli su sve to smjesta primijeniti na cijeli svijet. Svi su studenti učili iz djelovanja i situacija u drugim zemljama uz istodobno stjecanje bolje perspektive o svijetu. Svi prošli moduli ITHAS-a bili su uspješni, ali je izdanje 2021. godine dobilo potpuno novu dimenziju. Stoga će se koristi ITHAS-a 2021 točno i potpuno moći ocijeniti na osnovi analize upitnika koje su sudionici ispunili na početku, za vrijeme i nakon plovidbe, a rezultati ce možda motivirati planiranje sličnih prilika za isku- examples of how students were able to learn through practical experience.

Mega events require planning, execution, and a legacy. In UAE, the students had five days to visit and learn about Expo 2020. Expo (also known as world's fair) is an international event that takes place every few years wherein most countries from around the world showcase their achievements. A pre-event study surveying Dubai residents found that they like Dubai, are supportive of Expo 2020 as residents, and feel that Dubai should bid for other mega events (Tournois, 2018). Expo 2020 has a theme of "connecting minds, creating the future," with the subthemes of sustainability, mobility, and opportunity (Expo 2020 Dubai, n.d.). With free time to explore exhibits from 192 countries, students could learn from the initiatives happening across the world. For example, Laos has developed more efficient technology to clear the millions of unexploded bombs in their country, to make more land available for agricultural development. Another example is Belgium designing a virtual version of a major city, used to monitor things like traffic lights while also being able to simulate potential changes more economically and environmentally friendly. As students learned, Dubai has a strong legacy plan for Expo 2020, intending to make use of more than $85 \%$ of the site (Halligan, 2021). This is more sustainable than many past mega events. An environment like Expo 2020 has hundreds of teachers to learn from, from extremely diverse backgrounds, and this type of experiential learning students experienced on ITHAS 2021 is not something a classroom can imitate.

\section{CONCLUSION}

On this trip, students learned about culture, tourism, sustainability, sailing, and were able to apply this all to the world immediately. All students learned from the actions and situations of other countries while gaining a better perspective on the world. All 
stveno učenje budući da se vrijednost praktičnog iskustva u turizmu i ugostiteljstvu ne smije podcijeniti.

\section{LITERATURA - REFERENCES}

Arcodia, C., Čavlek, N., Abreu-Novais, M. (2014). Factors influencing motivations and expectations of field trip attendance. Current Issues in Tourism, Vol. 1, No. 1, pp. 37-41. DOI: https://doi.org/10.1080/1 3683500.2014.897309

Čavlek,N.(2015).Experiential learning in tourismeducation: The case of ITHAS.Tourism Social Science Series, Vol. 21, No. 1, pp. 101-113. DOI: https://doi.org/10.1108/ S1571-504320150000021005

Dicen, K. B., Yodsuwan, C., Butcher, K., Mingkwan, N. (2019). The institutional context for experiential learning investment in hospitality education: A case study from Thailand. In Liu \& H. Schänzel (Eds.), Tourism Education and Asia. Perspectives on Asian Tourism (pp. 143160). Springer.

Expo 2020 Dubai. (n.d.). available at https:// www.expo2020dubai.com/en/understanding-expo (accessed 7 December 2021)

Halligan, N. (2021, April 7). Dubai Expo 2020 Legacy: Site A Natural Fit for 2040 urban master plan, says delivery chief. The National. available at: https://www.thenationalnews.com/uae/ past ITHAS voyages have proved successful, but the 2021 edition was on a new scale entirely. Therefore, the exact benefits of the ITHAS 2021 experience will be fully evaluated on the basis of the analysis of the surveys carried out on the participants before, during and after the voyage. The results may motivate the design of similar experiential educational opportunities as in tourism and hospitality the value of practical experience should not be underappreciated.

government/dubai-expo-2020-legacysite-a-natural-fit-for-2040-urban-masterplan-says-delivery-chief-1.1198418 (accessed 8 December 2021) Ruhanen, L. (2006). Bridging the divide between theory and practice: Experiential learning approaches for tourism and hospitality management education. Journal of Teaching in Travel \& Tourism, Vol. 5, No. 4, pp. 33-51. DOI: https://doi. org/10.1300/J172v05n04_03

Tournois. (2018). A pre-event assessment of residents' reactions to Dubai Expo 2020. Tourism Management, Vol. 68, No. 1, pp. 46-51. DOI: https://doi.org/10.1016/j.tourman.2018.02.016

Primljeno: 3. prosinca 2021./

Submitted: 3 December 2021

Prihvaćeno: 13. prosinca 2021. I

Accepted: 13 December 2021

Ovaj je rad izdan pod licencom CC BY-NC (http://creativecommons.org/licenses/bync/4.0/).

This is an open access article under the CC BY-NC license (http://creativecommons.org/ licenses/by-nc/4.0/) 